\title{
Tectonics and mud volcano development in the Gulf of Cádiz
}

\author{
T. Medialdea a,*, L. Somoza a , L.M. Pinheiro ${ }^{\text {b }}$, M.C. Fernández-Puga ${ }^{\text {c }}$, J.T. Vázquez “, R. León ${ }^{a}$, M.K. Ivanov ${ }^{\text {e }}$, \\ V. Magalhaes ${ }^{\mathrm{b}, \mathrm{f}}, \mathrm{V}$. Díaz-del-Río ", R. Vegas ${ }^{\mathrm{g}}$ \\ a Marine Geology Division, IGME Geological Survey of Spain, Rios Rosas 23, 28003 Madrid, Spain \\ ${ }^{b}$ Departamento de Geociências and CESAM, Universidade de Aveiro, 3810-193 Aveiro, Portugal \\ ${ }^{c}$ Facultad de Ciencias del Mar; Universidad de Cádiz, Puerto Real, 11510-Cádiz, Spain \\ a Instituto Español de Cceanografia, Fuengirola 29640 Málaga, Spain \\ - UNESC Centre for Marine Geosciences, Moscow State University, Russia \\ ' Departamento de Geologia Marinha, Instituto Nacional de Engenharia, Tecnologia e Inovação I.P., 2721-866 Alfiagide, Portugal \\ s Departamento de Geodinámica, Fac. C. Geológicas, Universidad Complutense, 28040-Madrid, Spain
}

Keywords:

mud volcanoes

hydrocarbon seeps

fluid venting

diapirism

tectonics

Gulf of Cadiz

\begin{abstract}
A B S T R A C T
Many structures associated with fluid escape, including mud volcanoes, mud-carbonate mounds, pockmarks and slides, have been identified and characterized in the Gulf of Cádiz. Most of the mud volcanoes following NE-SW and NW-SE main trends are found at 350-2000 m depth in the eastern domain of the Gulf of Cádiz, which corresponds to the Betic-Rifean Margin. Scattered mud volcanoes have also been recognized on the lower slope at 2300-3900 m depth. The major tectonic structures are thrust faults, extensional faults, strikeslip faults and diapirs. All these tectonic structures have provided escape pathways for overpressured material and fluids or have favoured upward fluid movement along the sedimentary column and eventually the build up of mud volcanoes. In this work we present images of the mud volcano plumbing systems and the relationship between regional tectonics and mud volcano development. Seismic profiles acquired during the TASYO 2000 and MVSEIS/TIR-15

edifices and the subsurface tectonic structures.
\end{abstract}

\section{Introduction}

Data collected in the last few years have revealed the importance of sea-floor structures related to hydrocarbon fluid venting on the continental slope of the Gulf of Cádiz. Major fluid venting features in the Gulf of Cádiz have sizes ranging from kilometres to hundreds of metres and have been grouped into three main types: 1) pockmarks (Baraza and Ercilla, 1996; Casas et al., 2003; León et al., 2006); 2) mud volcanoes, some bearing gas hydrates in both the Iberian (Somoza et al., 2002; Pinheiro et al., 2003) and the Moroccan margins (Ivanov et al., 2000; Gardner, 2001; Kopf et al., 2004; Van Rensbergen et al., 2005); and 3) carbonate-mud mounds bearing carbonate chimneys, crusts and slabs (Díaz-del-Río et al., 2003; Magalhães et al., 2004; Fernández-Puga et al., 2007).

Three main relationships have been identified between mud volcano development and geological environments (Dimitrov, 2002): (1) the occurrence of a close relationship between mud volcanism and tectonics (Kopf, 2002; Huguen et al., 2004; Panahi, 2005), especially in compressional settings (Milkov, 2000); (2) the existence of deep potential source layers in the sedimentary succession (Feyzullayev et al., 2005); and (3) the location of mud volcanoes where hydrocarbons have been or are actively being generated (Guliyev and Feizullayev, 1997; Yusifov and Rabinowitz, 2004). The Gulf of Cádiz fulfils all these interrelations (Somoza et al., 1999, 2001; Garcia Mojonero and Martínez del Olmo, 2001; Ovsyannikov et al., 2003; Van Rensbergen et al., 2005; Pinheiro et al., 2006; León et al., 2007; Fernández-Puga et al., 2007).

To date, most of the published work on mud volcanism has been aimed at studying the fluid venting structures, the morphology and geometry of the edifices and the geochemistry and origin of the fluids. Little attention has been paid to mud volcano occurrence in relation to tectonics, which is still poorly constrained. The large number of mud volcanoes identified in the Gulf of Cádiz, their distribution along different sectors of the margin and their location in different tectonic settings provides the possibility of studying the development of mud volcanism in a tectonically active area under a compressive/transpressional regime with a high level of seismicity. In this work we image and document the relationship between tectonics and mud volcano development on the Betic-Rifean margin and lower slope. With this aim we use seismic profiles acquired during the TASYO Project and the MVSEIS/TTR-15 cruises to analyze the "mud volcano system" structure and the relationship between its genesis and tectonics. The images presented correspond to "mud volcano systems" located in different sectors of the continental slope, where the tectonic structure varies. 
We use the term "mud volcano system" in the sense given by Stewart and Davis (2006): "a set of structures associated with a constructional edifice (mud volcano) and the feeder complex that connects the volcano to its source stratigraphic unit".

\section{Geological background}

The present geological structure of the Gulf of Cádiz is the result of the European-African plate convergence motion, dextral strike-slip along the Azores-Gibraltar Plate Boundary and the westwards migration of the Betic-Rifean Arc. This plate convergence lasted from Mid-Oligocene up to Late Miocene times and then continued with slow Late Miocene to Recent NW convergence (Dewey et al., 1989; Vázquez and Vegas, 2000; Rosenbaum et al., 2002). Westward drift and collision of the Alborán Domain with the North African and southem Iberian margins in the EarlyMiddle Miocene caused the development of the Betic-Rifean Belt (Figs. 1 and 2) and as a consequence the radial emplacement of huge allochthonous masses (the so-called "Olistostrome Unit"), here named the Allochthonous Unit of the Gulf of Cádiz (AUGC), on the Guadalquivir Basin (Iberian foreland), the Rharb Basin (North African foreland) and the Gulf of Cádiz (Torelli et al., 1997; Maldonado et al., 1999; Medialdea et al., 2004).

This complex geodynamic evolution is recorded in the architecture and tectonic structure of the continental margin of the Gulf of Cádiz, which has a series of physiographic, morphological and geological features and a geodynamic framework that have focused the attention of many researchers. Among these features, the following stand out: 1) an irregular physiography, with an outstanding development of a broad continental slope; 2) the emplacement of a chaotic body, the AUGC, which occupies the central part of the Gulf of Cádiz; 3) complex tectonics with large-scale diapiric processes throughout the entire continental margin; 4) the occurrence of gas and gas hydrates, and eventually 5) the formation of seafloor features related to hydrocarbon seepage, including many mud volcanoes (Fig. 1). All these geological features are in a close relationship.

The continental slope extends from $140 \mathrm{~m}$ depth to the Horseshoe and Seine abyssal plains, reaching a width of about $300 \mathrm{~km}$ (HemándezMolina et al., 2003). The sedimentary cover of the slope consists of Triassic to Quatemary materials (Maldonado et al., 1999), and ranges in thickness from: 2-2.5 s Two-Way Travel Time (TWTT) on the middle continental slope to 2-3.5 s (TWTT) on the lower slope, and again to 2-2.5 s (TWTT) on the abyssal plains (Medialdea et al, 2004). The AUGCmentioned above represents the thickest unit of the sedimentary cover (Fig. 1B). It is a wedge-shaped unit which extends from the Iberian Peninsula and Morocco to the Horseshoe and Seine Abyssal Plains. The structure consists of low-angle thrust sheets affected by later gravitational collapse and reactivated thrusting (Torelli et al., 1997; Maldonado et al., 1999; Medialdea et al., 2004). The AUGC consists of a mixture of Triassic, Cretaceous, Paleogene and Neogene sedimentary units, overlying a Palaeozoic basement (Maldonado et al., 1999). It involves a huge volume of mud and salt diapirism of Triassic salt units and undercompacted EarlyMiddle Miocene plastic marls (Maestro et al., 2003). The origin of this chaotic body is highly controversial. It has been interpreted as a complex of olistostromes caused by gravitational sliding and thrust tectonics (Torelli et al., 1997; Medialdea et al., 2004). Its emplacement on the Atlantic realm has been related to the westem migration of the Alborán terrain as a consequence of an once active subduction zone (Royden, 1993; Lonergan and White, 1997; Rosenbaum et al., 2002; Medialdea et al, 2004; Iribarren et al., 2007). Alternatively, Gutscher et al. (2002) proposed that this subduction is still active beneath Gibraltar. There is a general agreement on the age of emplacement of this unit, which has been established as Late Tortonian in the Gulf of Cádiz (Torelli et al., 1997; Maldonado et al., 1999; Somoza et al, 1999; Medialdea et al., 2004), although the AUGC was later reactivated in the Late Miocene to Present as the result of the NW compression. This feature appears as a chaotic, highly diffractive body on the seismic profiles. The chaotic character atributed to the AUGC is due to its heterogeneous composition and internal deformation produced by diapirs, strike-slip faults, extensional faults, thrust faults, slides and fluid venting structures (Figs. 1 and 2). Extensive mud diapirism has been reported throughout the Gulf of Cádiz margin, especially on the slope (Somoza et al, 1999; Maldonado et al., 1999; Lowrie et al., 1999; Maestro et al., 2003; Somoza et al., 2003; Fernández-Puga et al., 2007).

Along the Gulf of Cádiz continental margin, the origin of hydrocarbon-related fluid venting structures is related to the occurrence of both thermogenic and biogenic gas within the AUGC (Maldonado et al., 1999; Mazurenko et al., 2003). The 50 mud volcanoes confirmed by coring so far are cone-shaped sea-floor edifices ranging from 800 to $3500 \mathrm{~m}$ in diameter, which can tower in places up to $300 \mathrm{~m}$ above the seabed. They are produced by mud and fluid (water, brine, gas, oil) eruptions as the result of degassing processes in deeper reservoirs (Hensen et al., 2007), intercalated with periods of inactivity. Most mud volcanoes are built up of episodes of mud-breccia flows (Somoza et al., 2003; Van Rensbergen et al., 2005) with evident indications of gas saturation: degassing structures, a strong $\mathrm{H}_{2} \mathrm{~S}$ smell and chemosynthetic fauna (e.g. Pinheiro et al., 2003; Somoza et al., 2003).

\section{Methodology and data sources}

The results of this work are mainly based on the interpretation of multichannel seismic profiles collected during the TASYO 2000 cruise along the Iberian margin and in deep waters on the lower slope (Fig. 3 ) in the framework of the MVSEIS Project and the UNESCO IOC TTR Programme. Data related to new mud volcano discoveries obtained recently on the MVSEIS08 Cruise have also been added. This work would not have been possible without the results obtained from the extensive dataset acquired during several surveys carried out aboard the Prof. Logachev, Hespérides and Cornide de Saavedra research vessels, which allowed discovering and investigating the diverse sea-floor structures related to fluid venting along the Gulf of Cádiz. An important contribution was also provided by the side scan sonar mosaic of Dr. Joan Gardner from the Naval Research Laboratory, Washington DC (Gardner, 2001). During these cruises, in addition to swath bathymetry data obtained with a multibeam echosounder (Simrad EM-12), the geophysical data acquired include multichannel and single-channel seismic reflection profiles, surface $(12 \mathrm{kHz})$ and high resolution deep-towed $(30-100 \mathrm{kHz})$ side scan sonar and underwater video profiles. Targets of interest previously selected on multibeam bathymetric maps, backscatter maps and seismic profiles were sampled with dredges, TV-controlled grabs and gravity cores.

The seismic dataset presented in this work includes high- to mediumresolution seismic profiles that were obtained with a Topographic Parametric Echosounder (TOPAS) with a maximum penetration of $100 \mathrm{~m}$ and a Sparker system with an energy source of 3500-7000 J and a recording length of $2 \mathrm{~s}$. The seismic data were recorded using Delph2 Triton Elics-software. Furthermore, $1728 \mathrm{~lm}$ of multichannel seismic profiles were obtained during the TASYO 2000 cruise (Fig. 3). The mulichannel seismic data were acquired with a five BOLT airgun array of 22.45 and $34.8 \mathrm{l}$ capacity and a TELEDYNE 96-channel streamer of $2.5 \mathrm{~km}$ length, and were recorded for $10 \mathrm{~s}$ at a $2 \mathrm{~ms}$ sampling rate. The shot interval was $50 \mathrm{~m}$. Seismic data were poststack time-migrated at the Instituto Andaluz de Ciencias de la Tierra. Fledermouse software was used to analyze the multibeam data, and Kingdom Suite software was used to produce the seismic images.

\section{Results}

\subsection{Tectonics and diapirism}

The NW to WNW-directed compressional regime is responsible for the development of NE-SW, ENE-WSW, NW-SE and WNW-ESE tectonic structures on the lower slope and abyssal plains, where either the sedimentary cover or the continental and oceanic basement are involved (Fig. 1). Compressional structures consist of thrust faults and 
A

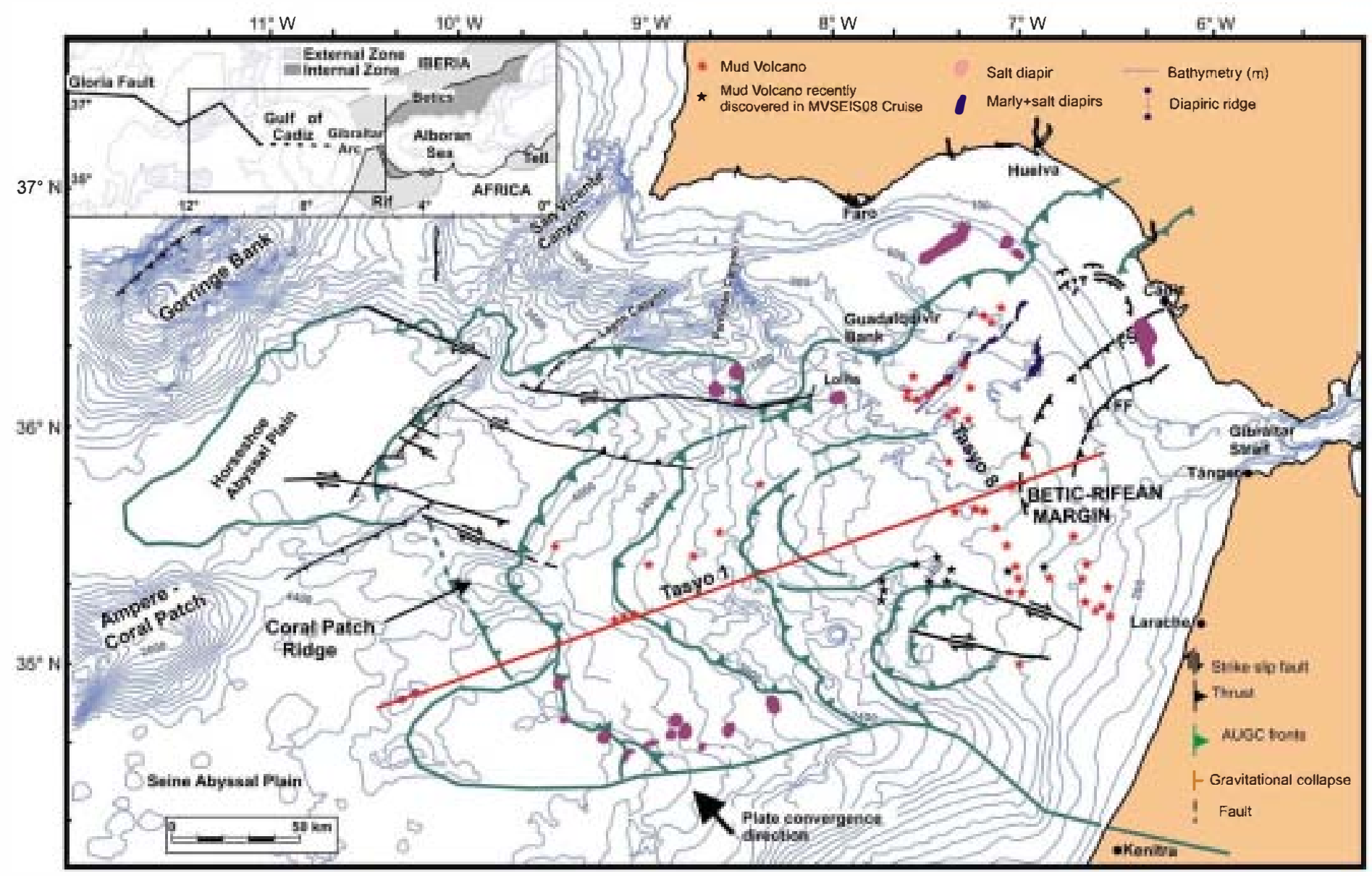

B

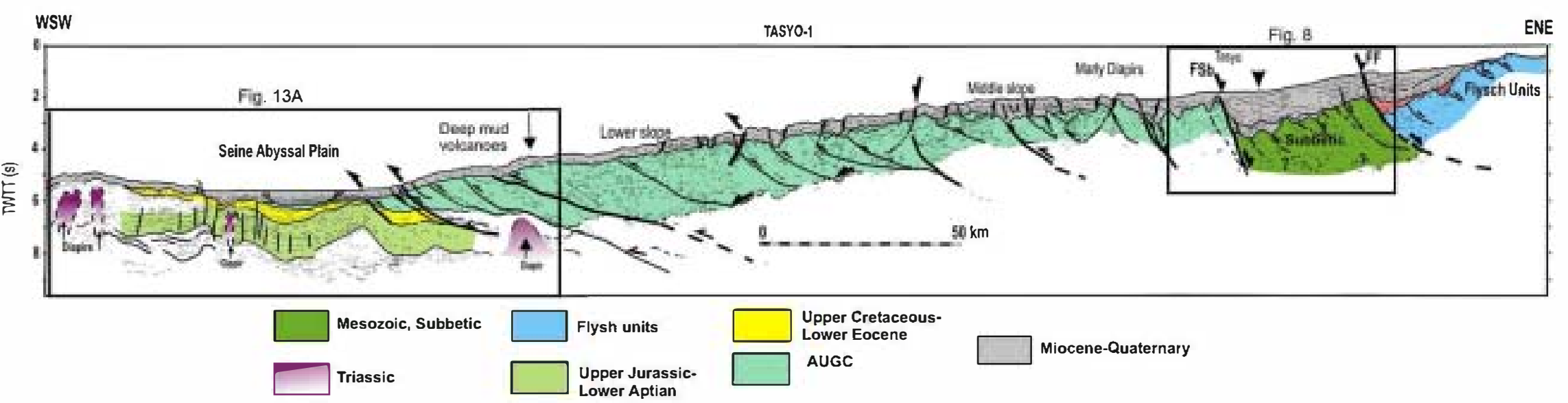




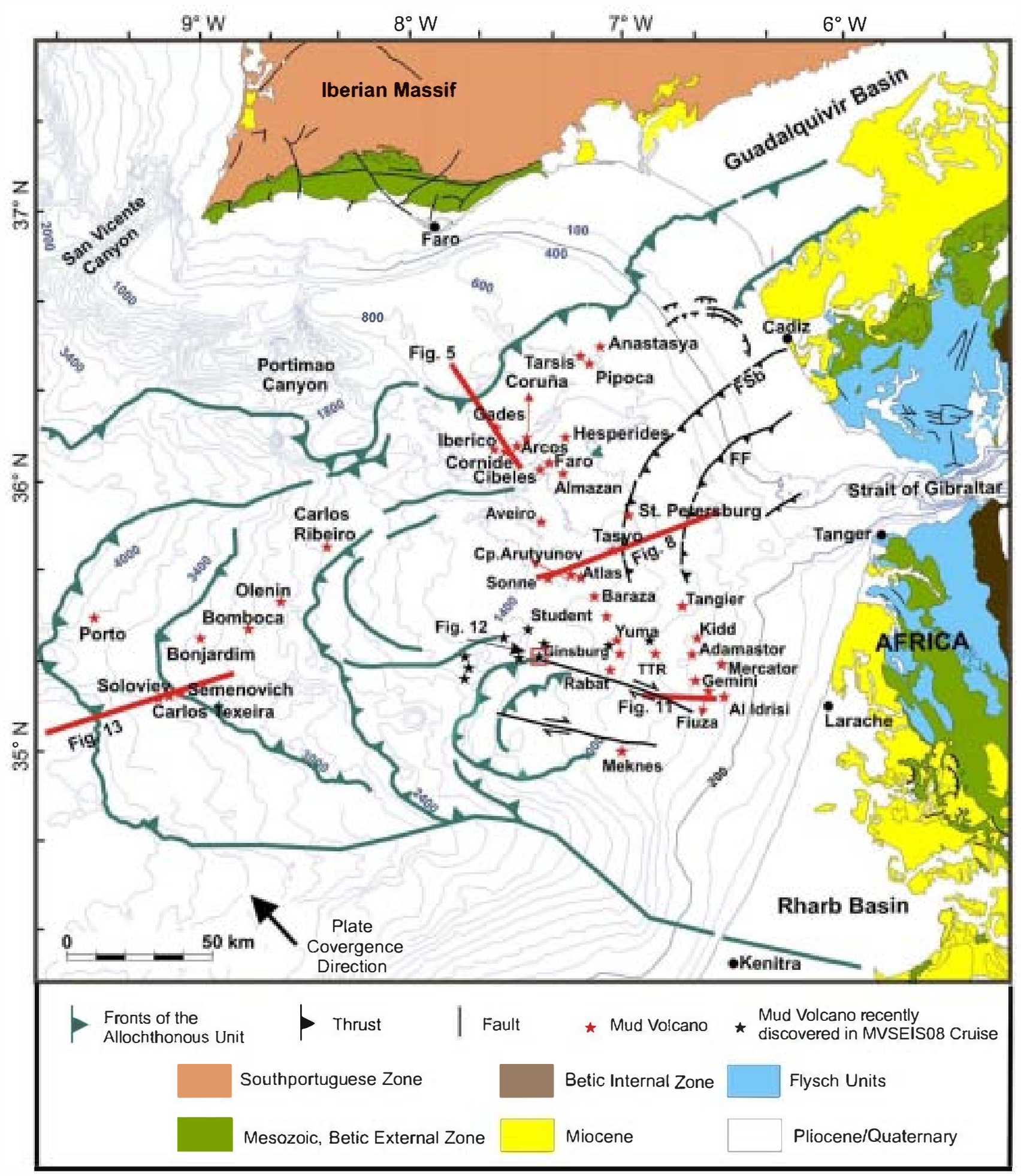

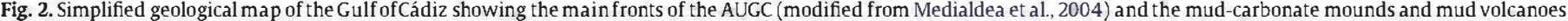

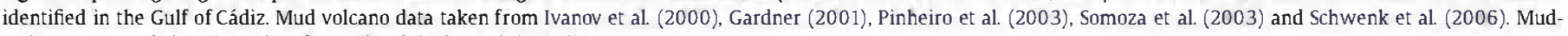
carbonate mounds location taken from Díaz-del-Río et al. (2003).

folds related to deformation of the basement and the sedimentary cover or to diapiric structures. Major extensional structures consist of a system of listric faults on the continental shelf in front of Cádiz, rooted at the AUGC, which bound the diapiric ridges to the north (Fig. 1).
Extensional faults were produced by the gravitational collapse at the back of the AUGC as it advanced seaward in the Pliocene-Quaternary (Somoza et al., 1999; Maestro et al., 2003; Fernández-Puga et al., 2007). Other extensional structures are normal faults rooted at the top of

Fig. 1. A) Map of the Gulf of Cádiz (modified f rom Medialdea, 2007) based on interpretation of MCS lines with the location of main outcropping and very shallow diapirs, faults, mud volcanoes and mud-carbonate mounds. FSb: Subbetic Front; FF: Flysch Front. Mud volcanoes recently discovered after Somoza et al. (2008). B) Line-drawing derived from the MCS profile TASYO 1 that crosses the Gulf of Cádiz. See Fig. 1A for location. 
diapirs (crestal faults), which can reach the sea-floor. Transcurrent structures are active right-lateral strike-slip faults trending NW-SE to WNW-ESE (Fig. 1), with a compressional component situated on the lower slope, in the northeastern part of the Horseshoe Abyssal Plain and Coral Patch Ridge (Medialdea et al., 2004; Medialdea, 2007) and on the Moroccan margin. Two types of diapirism have been recognized on the seismic profiles (Fig. 1): salt diapirism related to the Mesozoic evaporites and marly diapirism associated with the AUGC (Medialdea, 2007; Fernández-Puga et al., 2007). The main halokinetic structures are concentrated on the continental shelf and upper-middle slope of the Iberian margin and on the Moroccan slope (Figs. 1 and 4). Buried diapirs have also been recognized in seismic profiles in the central and western part of the Gulf of Cádiz (Fig. 1B). On the South Portuguese margin, the diapirs are made up of lower Jurassic and Triassic evaporites that overlie the basement (Terrinha et al., 2002). They can be identified on the bathymetric map (Fig. 1) as rounded domes that deform the sea-floor, such as the Lolita diapir (Figs. 1 and 4), but in other cases they do not crop out. These diapirs were formed after the AUGC emplacement in the upper Miocene, because they cut through it. On the Moroccan margin, several salt domes of $3-5 \mathrm{~km}$ diameter were mapped with multibeam data acquired on the TASYO-2000 and GAP cruises (Fig. 1A and B). They follow ENE-WSW trends, have oval or rounded morphologies and cut and deformed almost the whole sedimentary cover. These diapirs are constituted by Triassic evaporites deposited during the early rifting phase that gave rise to the opening of the Atlantic (Pautot et al., 1970).

The formation of marly diapirs in relation to the AUGC has been studied on the Iberian margin (Fig. 1A). They are mainly composed of Miocene clay and marls and Triassic evaporites and are represented by rounded or oval domes slightly buried or outcropping. The diapirs are grouped forming NE-SW ridges, parallel to the Subbetic Front (FSb in Fig. 1A), up to $85 \mathrm{~km}$ long and $4 \mathrm{~km}$ wide, producing a relief of $250 \mathrm{~m}$ (Somoza et al., 2003; Fernández-Pugaet al., 2007). The largest diapiric structures are the Cádiz Diapiric Ridge, the Guadalquivir Diapiric Ridge and the Doñana Diapiric Ridge, with lengths of 43, 86 and $53 \mathrm{~km}$, respectively (Figs. 4 and 5). The genesis of marly diapirs has taken place from the upper Miocene to Present and has been related to extensional or compressional tectonics.

\subsection{Fluid escape pathways and tectonics}

Fluid migration appears to be fault-controlled (Somoza et al., 2003; Medialdea et al., 2004; Pinheiro et al., 2006; Fernández-Puga et al., 2007). As noted above, in the Gulf of Cádiz the major tectonic structures are thrust faults, strike-slip faults, extensional faults and diapirs, which have been mapped from multichannel seismic data (Somoza et al., 1999; Maldonado et al., 1999; Medialdea et al., 2004). All these tectonic structures have favoured the upward fluid movement and/or have provided an escape pathway for overpressured material and fluids along the sedimentary column to eventually build up the mud volcanoes.

Mud volcanoes are distributed in three main areas of the Gulf of Cádiz (Figs. 1 and 2). Most of them are found on the slope at 350$2000 \mathrm{~m}$ depth, either on the northern Iberian margin (Tasyo and GDR mud volcano fields) trending NE-SW (León et al., 2001; Somoza et al., 2003; Díaz-del-Río et al., 2003) or on the Moroccan margin (the Al Arraiche mud volcano field), following an approximately NW-SE direction (Mazurenko et al., 2003; Pinheiro et al., 2003; Van Rensbergen et al., 2005; Pinheiro et al., 2006). Both of these margins represent the offshore prolongation of the Betic-Rifean Belt and the corresponding foreland basins (the Guadalquivir Basin in the Iberian Peninsula and the Rharb Basin in Morocco, to the north and south of the Gibraltar Arc). The occurrence of mud volcanoes seem to diminish westwards, where relatively few single mud volcanoes have been identified on the lower slope at 2300-3900 $\mathrm{m}$ depth.

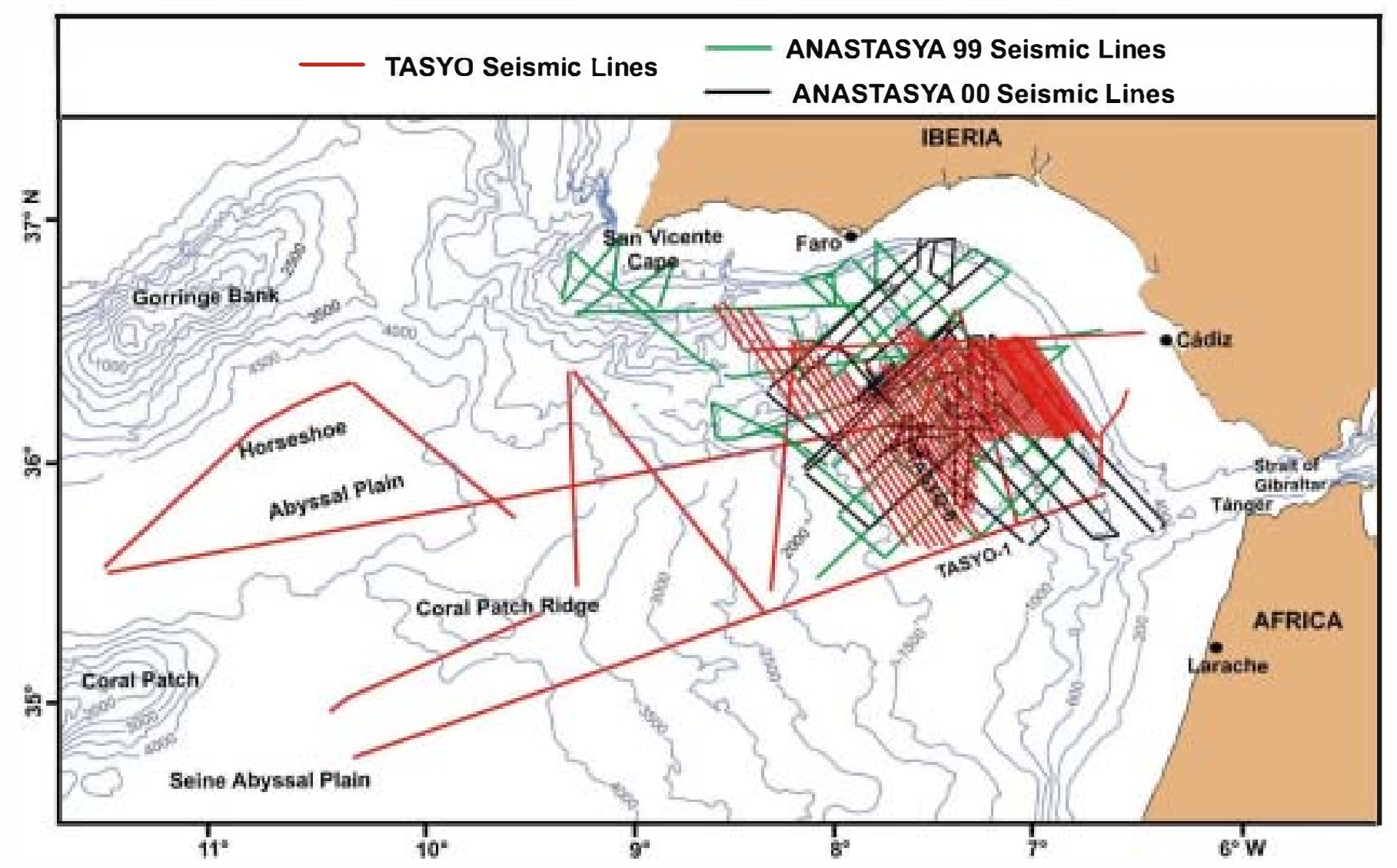

Fig. 3. Location of TASYO multichannel seismic lines and previous surveys (Anastasya9s and Anastasya00) in the Gulf of Cádiz. 


\subsubsection{Betic-Rifean margin}

In this part of the margin, major NE-SW and NW-SE trends are determined by the Betic and AUGC structures (Figs. 1 and 2). The region is characterized by successive arcuate thrusts corresponding from $\mathrm{E}$ to $\mathrm{W}$ to the Flysch and Subbetic materials in the internal area and to the AUGC in the more externaldomains. Westwards the basement dips to the east, under a sedimentary cover of about 2.5-3 s (TWTT) thickness, which corresponds mainly to the AUGC, structured in thrusting sheets that advance seaward, reaching progressively further distances along a seaward-dipping basal surface. This sector of the margin is characterized by salt and marl nappes which were later affected by extensional collapses, the widespread development of diapirs associated with the AUGC and a great variety of fluid venting structures above them, including numerous mud volcanoes and mud-carbonate mounds that

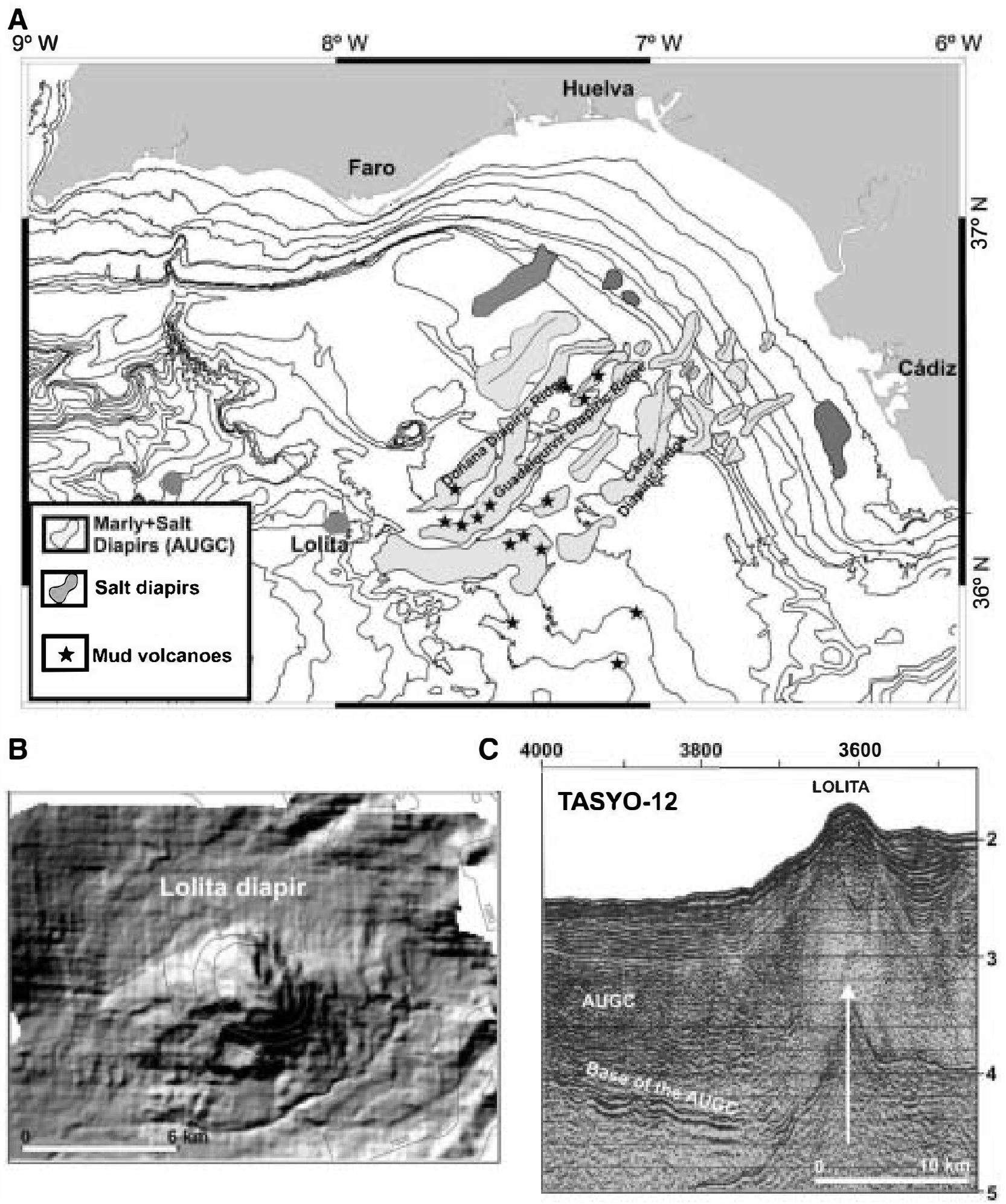

Fig. 4. A) Map of the shale/salt diapirs and NE-SW trending diapiric ridges on the upper-middle slope of the Gulf of Cádiz (Modified from Fernández-Puga et al., 2007); B) Bathymetric map of the Lolita salt diapir obtained with multibeam data; see Figs. $1 \mathrm{~A}$ and $4 \mathrm{~A}$ for location; C) Multichannel seismic profile across the Iolita salt structure where the diapir can be observed rising from below the AUGC. 
clearly control the slope morphology (Fig. 1A). According to seismic and well data (Maldonado et al., 1999), the allochthonous masses involved in the continental shelf and upper slope are Miocene clays and marls (Langhian to Upper Tortonian), fragments of Mesozoic and plastic Triassic materials and even lower Cenozoic units.

Mud volcanoes are located at a depth range (350-2000 $\mathrm{m}$ ) similar to that of other mud volcano clusters found on the Mediterranean Ridge (Camerlenghi et al., 1995; Huguen et al., 2004), the Black Sea (Dimitrov, 2002; Bohrmann et al., 2003) and California (Orange et al., 1999). They are associated with shallow/outcropping or buried diapirs that form a set of parallel ridges, as can be clearly observed in the multichannel seismic line TASYO 8 (Fig. 5). This line crosses the Bank of Guadalquivir, a basement high where Variscan rock outcrops, and the NE-SW Doñana and Guadalquivir diapiric ridges which display a NESW trend, parallel to the Bank (Fig. 1). Along the profile and from NW to $\mathrm{SE}$, the size of the diapirs increases while the depth of the diapir crests decreases. The AUGC is covered by Pliocene-Quaternary sediments folded and deformed by the upward migration of the diapirs almost to the sea-floor, indicating that these structures were active until recent times. Chaotic and transparent seismic facies suggesting the presence of gas usually appear at the top of these diapirs and dome structures and sometimes in the overlying sediments. These transparent facies disappear towards the surface at about 300-500 ms (TWIT) below the sea-floor (Fig. 5). Faults generated on top of the diapirs as a consequence of their emplacement establish a pathway for transport and fluid migration.

The Doñana Diapiric Ridge is represented in line TASYO 8 by the diapirs located next to the Guadalquivir Bank (Figs. 4 and 5). The Gades mud volcano is found over this ridge very close to this seismic line (Fig. 6), and is clearly linked to a diapir next to the Guadalquivir Bank, as can be observed in Fig. 5. Fluid expulsion through the sediments, and subsequent mass deficiency generate a gravity collapse. A collapse is clearly imaged under the volcano by broken concave reflections related to the fluid and mud evacuation towards the overlying mud volcano and the extensional faults that link the summit of the diapir at $860 \mathrm{~m}$ depth to the sea-floor (Fig. 6). The Gades mud volcano, whose 3D image is displayed in Fig. 6A, is found at the crosspoint of one of these faults with the sea-floor, where upward-dipping reflectors indicate mud and fluids ascending to the sea-floor. Transparent facies, indicating gas occurrence, have been observed within the diapir and the sediments found over the NW diapiric flank, which extends to the Guadalquivir Channel (Fig. 5).
Towards the SE, the seismic profile TASYO 8 crosses the Guadalquivir Diapiric Ridge, next to the Ibérico and Cornide carbonate-mud mounds (Fig. 7), where abundant carbonate crusts and chimneys were collected (Díaz-del-Río et al., 2003). The mud mounds appear to be linked to a shallower diapir, connected to the sea-bottom through several conduits marked by acoustic blanking. No collapse is observed. The feeder system is more complex if we consider that the ridge appears to be also fed from a nearby diapir, as can be inferred from the transparent facies that extends from its summit to the Cádiz channel at the base of the scarp of the Guadalquivir Diapiric Ridge. In this case there is a multiple source, so the fluid flux should be more diffused.

Southwards, the Tasyo mud volcano is located between the Iberian and Moroccan margin and was crossed by seismic line TASYO 1 (Figs. 2 and 8 ). It is a volcano linked to a deep and small diapir (1350 $\mathrm{m}$ depth from sea-bottom) piercing a basin (Fig. 9) that surrounds the Subbetic Front (Fig. 1). This basin is filled by a middle Miocene-Quaternary depositional sequence of more than 1.5-2 s (TWTT) thick at the back of the AUGC, formed by the subsequent extensional collapse of the westwards advancing allochthonous masses (Fig. 1B).

Under the mud volcano, in the detail of multichannel seismic profile TASYO 1, we can differentiate an outcropping edifice over a buried one, forming two stacked bicones and a common feeder system, which give the typical image of a Christmas tree (Figs. 9 and 10) similar to that observed on the Anastasya mud volcano (Somoza et al., 2003). The Christmas tree appearance reveals different periods of activity (Somoza et al., 2003). The bicones are about $300 \mathrm{~m}$ high and $3-3.5 \mathrm{~km}$ wide (Fig. 10A). The upper one is more sharply defined, with reflections ending against the boundary of the bicone. The bicones are connected to the diapir by crestal faults that develop on top of its summit and constitute the system that feeds the bicones. The occurrence of a stack of two bicones bears witness to two major episodes of mud and fluid migration and extrusion activity over time, with a very short dormant period between them, as can be concluded from the lack of a sedimentary layer between them. The bicones are formed by an initial cone link to a feeder system connected to the overpressured mud (Stewart and Davies, 2006). The formation of the bicones is due to the later subsidence and collapse of the mud volcano edifice.

Finally, we can conclude from the map displayed in Fig. 1, that mud volcanoes of the Moroccan margin are distributed along a NW-SE direction, probably corresponding to NW-SE strike-slip faults that intersects the arcuate thrusts of the margin (as reported by Pinheiro et al., 2003, 2006; Somoza et al., 2008). These strike-slip faults can be

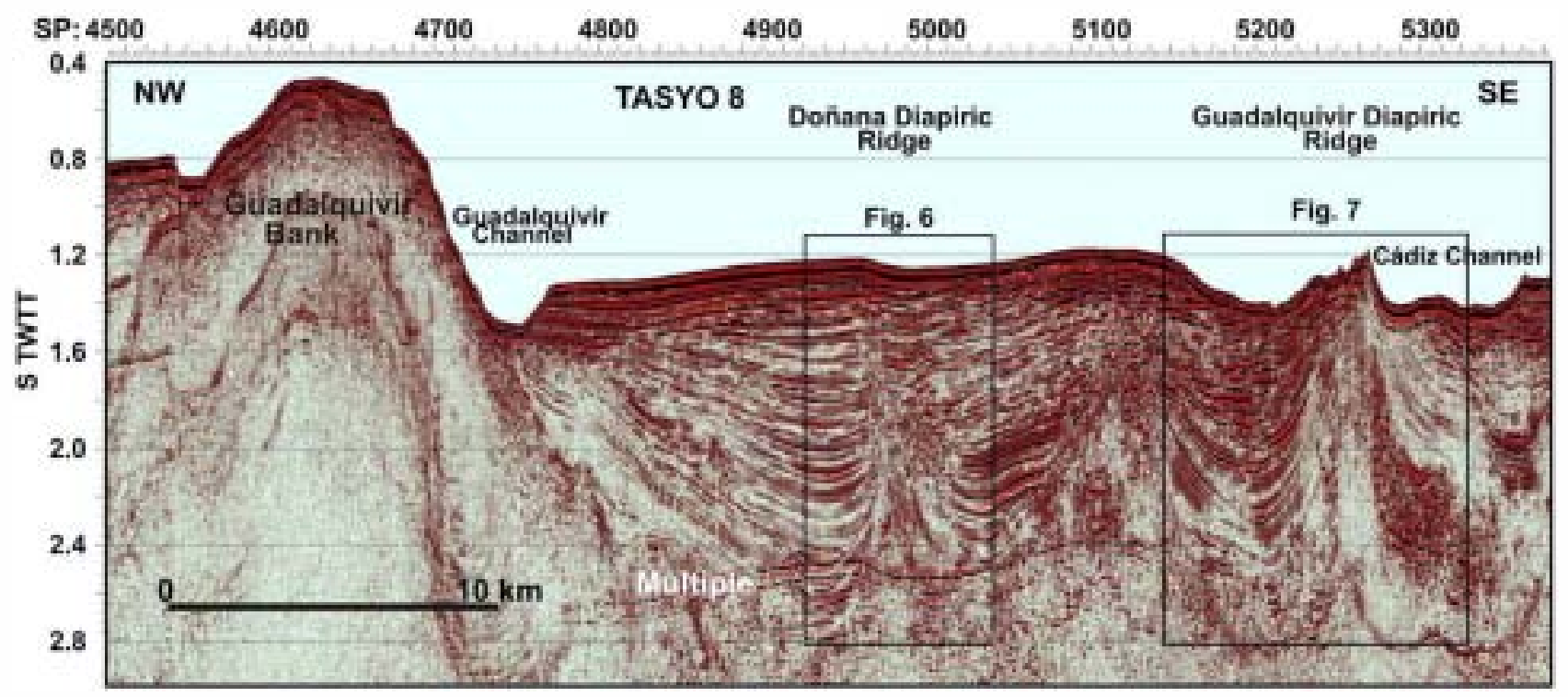

Fig. 5. Multichannel seismic line TASYO 8 across the Doñana and Guadalquivir Diapiric ridges. See Fig. 2 for location. Inset shows location of Figs. 6 and 7. 
mapped with the side scan sonar and high resolution seismic profiles and are very important structures in the eastem sector of the Gulf of Cádiz (Fig. 11). During the MVSEIS08 Cruise (Somoza et al., 2008), ten new mud volcanoes associated with strike-slip and thrust faults were discovered and sampled (Fig. 12).

\subsubsection{Lower slope}

Though the deep waters of the margin were investigated on the last TTR cruises (Schwenk et al., 2006; Pinheiro et al., 2007) in the framework of the MVSEIS Project, only a few mud volcanoes were identified on the lower slope of the Gulf of Cádiz, compared to the BeticRifean margin. Three of them, the Semenovich, Soloviev and Carlos Texeira mud volcanoes are crossed by the multichannel seismic line TASYO 1 at about $3400 \mathrm{~m}$ depth (Figs. 1, 2 and 13). In this domain, the AUGC reaches its maximum thickness and is characterized by a change in dip of its basal surface, whose vergence shifts from oceanward to landward. On the profile the western end of the AUGC can be observed; in factthe volcanoes are found not very far from the external front of the AUGC, close to the base of the slope and the Seine Abyssal Plain (Fig. 13). The AUGC overlies Mesozoic to Paleogene materials and is covered by Pliocene-Quaternary sediments. The base of the AUGC is defined by a strong and continuous reflector that disappears at shot point (S.P.) 300 , just below the mud volcanoes (Fig. 13). This can be explained by the occurrence of a diapir that pierces the AUGC from below and has been interpreted as a salt diapir that cuts the AUGC. At this point, it must be remembered that outcropping or almost outcropping salt diapirs are very frequent in the area, as displayed on the bathymetric map and seismic profiles, where several domes disturb the seabed (Fig. 1). In the first step, the salt diapir would favour the ascent of the fluids, which were probably trapped in a deep reservoir found at the Mesozoic unit, between $6.5-8$ s (TWTT), above the salt. Eventually, migration appears to be fault-controlled. As observed in Fig. 13C, several thrust planes in the AUGC are linked to the superficial edifices of the mud volcanoes. These low-angle planes are observed as high-amplitude reflectors

A
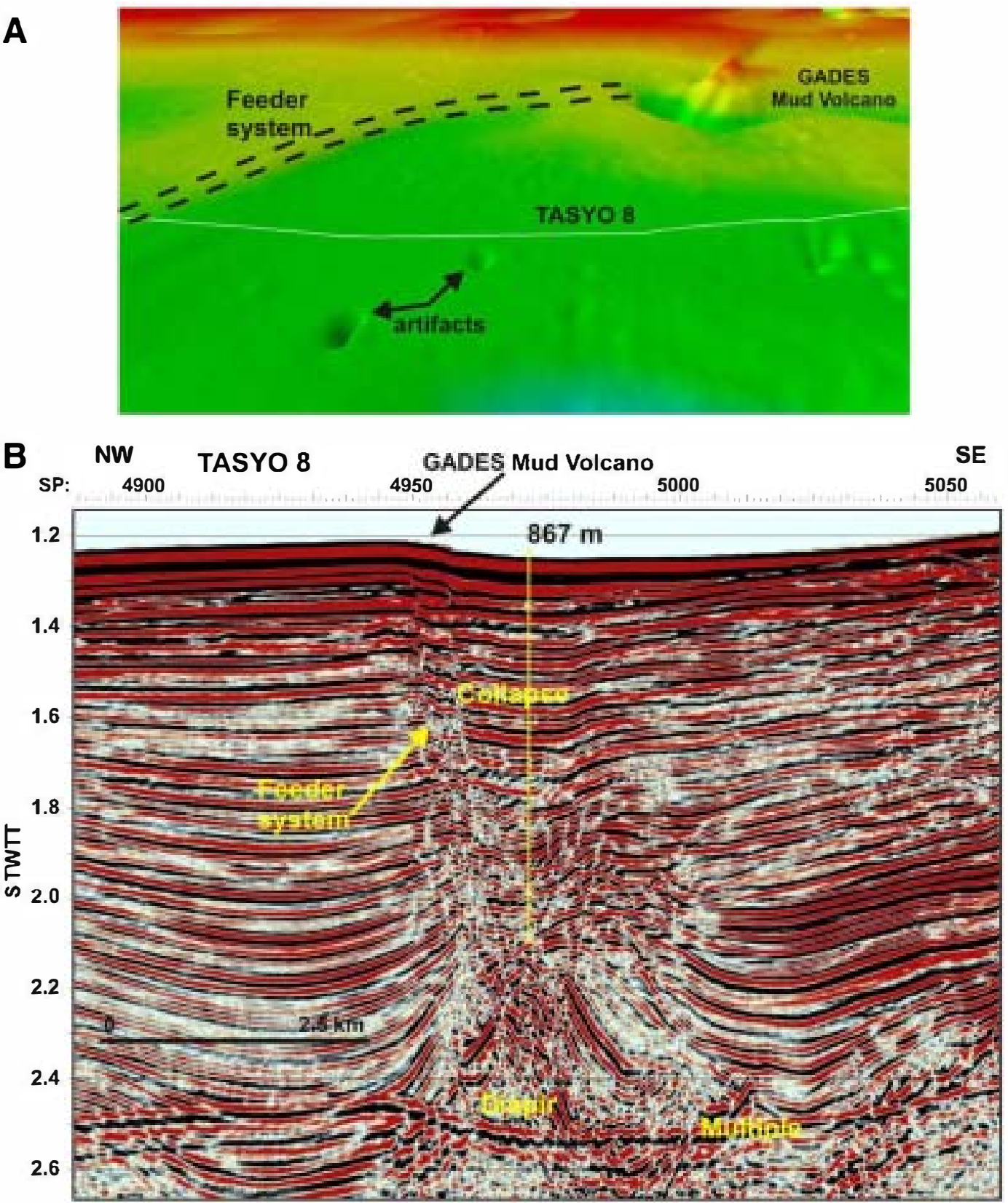

Fig. 6. A) 3D bathymetric image of the Gades mud volcano. B) Detail of the multichannel seismic line TASYO 8 across the Gades mud volcano. See Fig. 5 for location. 
within the AUGC. Therefore, in this case the development of the mud volcanoes is related to the fault system of the AUGC and the salt diapirs, but not to the marly clay diapirs associated with this unit in other areas. Thrust fault planes acting as conduits seem to have connected the source and the superficial mud volcano edifice, after the fluid escape took place aided by the ascending diapir. A study of the gas from mud volcanoes on the lower slope (Bonjardim and Carlos Ribeiro) points to a mixture of thermogenic and biogenic gas and redeposition of the migrated/mixed gas at shallow depths, possibly within the AUGC and/ or Pliocene-Quaternary material (Mazurenko et al., 2003; Stadniskaia et al., 2006).

\section{Discussion}

As derived from the analysis of seismic profiles, the build up of mud volcanoes in the Gulf of Cádiz comprises two main steps: an initial step related to diapirism and a second step of fault-controlled fluid and mud-flow extrusion and building of the mud volcano edifices. Tectonics plays two main roles in the genesis of mud volcanoes: firstly, it is responsible for the development of pressurized compartments and secondly, faults and diapirs favour the mud and fluid rise from the source along faults and fractures. Seismic images suggest that several structures (extensional, strike-slip or

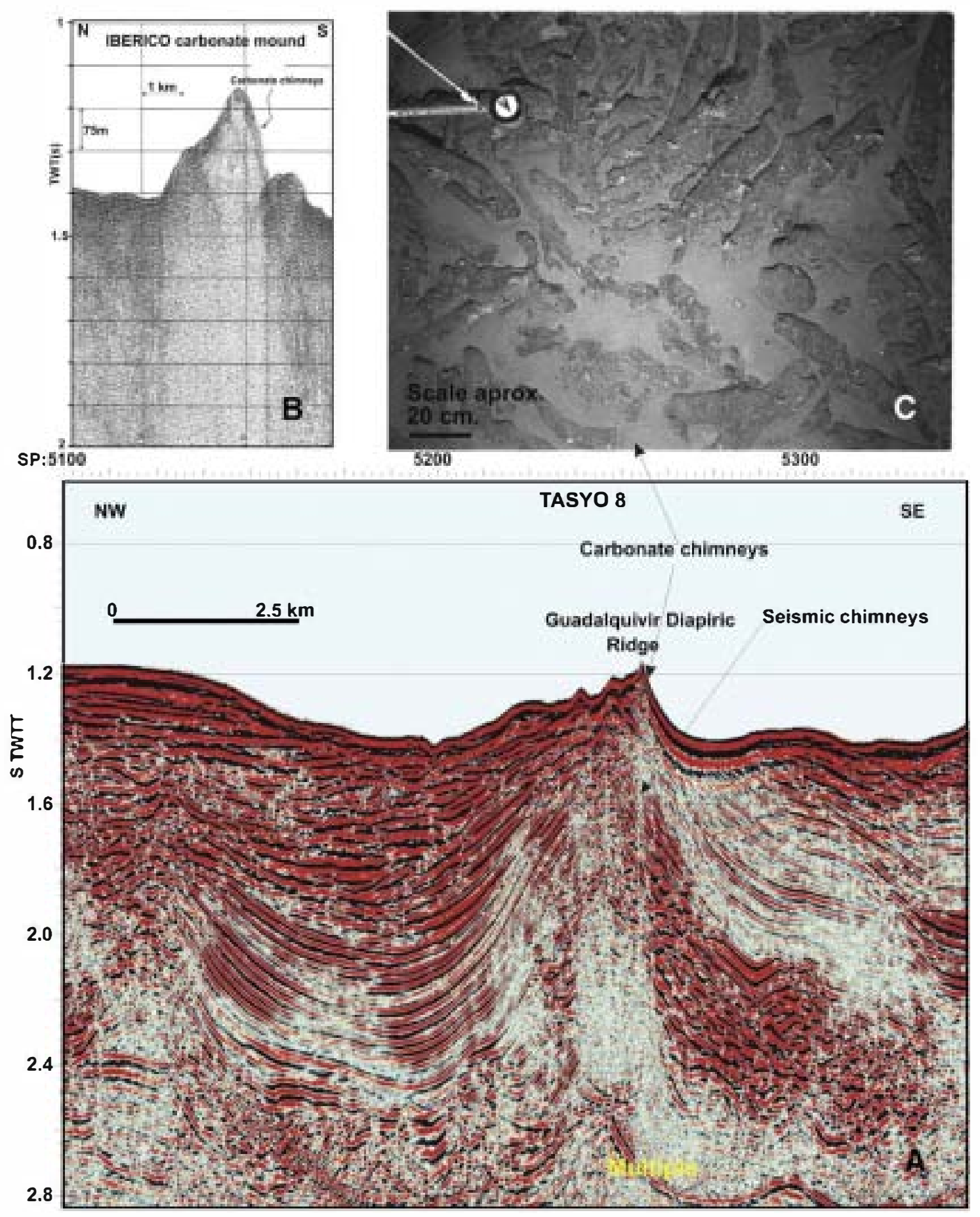

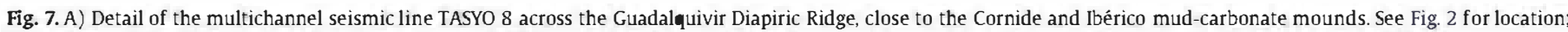
B) Sparker profile of the Ibérico carbonate-mud mound; C) Underwater picture of the carbonate chimneys lying at the sea-floor taken during the Anastasya 00 cruise. 
compressional faults) along the margin have acted as efficient conduits.

\subsection{Fluid sources}

In all the mud volcanoes we have dealt with, the source of the mud volcano system in the Iberian margin is the AUGC. Nevertheless, the existence of deeper sources below the AUGC, probably of Mesozoic age, is clearly suggested at least for the deep water mud volcanoes, as can be inferred from the seismic image of the Semenovich and Soloviev mud volcano system (Fig. 13). In this case, the source is believed to be located at the base of the AUGC and a salt diapir and a thrust fault provide the connection between the mud volcano and the deep-sited hydrocarbon reservoirs. The existence of different sources is supported by the two processes of gas generation invoked in the Gulf of Cádiz (García Mojonero and Martínez del Olmo, 2001): biogenic gas expelled by upper Miocene shales and thermogenic gas generated by the AUGC. In the second case, it is unknown whether its main generation phase took place at its current location or at its place of origin. Gas generation in Mesozoic source rocks and fluid flow along the basal detachment of the AUGC has also been suggested as a possible source of fluid injection (Van Rensbergen et al., 2005).

In addition, the composition of the gases from the gas hydrates recovered from mud volcanoes (Ginsburg, Bojardin and Captain Arutyunov) indicates a thermogenic origin, which suggests the possible existence of hydrocarbons at depth (Mazurenko et al., 2003; Pinheiro et al., 2006). Moreover, variations in pore fluid isotopic composition indicate a mixing of thermogenic and biogenic methane rich fluids (Mazurenko et al., 2003), reflecting the existence of changes in the sources of fluid venting. Molecular and carbon isotopic variability of hydrocarbon gas in mud volcanoes located on the lower slope and on the Moroccan margin reveal two groups of gases that may belong to the same source beds but with different maturation characteristics, and suggest the presence of hydrocarbon accumulations in the deep subsurface (Stadniskaia et al., 2006). The same results have been obtained by the characterization of organic matter in carbonate chimneys and Fe-Mn nodules, which support a thermogenic origin as well the existence of deep reservoirs (González et al., 2009-this issue).

Mud volcanism is initiated when overpressured fluid muds rise through the sediments and reach the sea-floor. Compressional tectonics is possibly the main cause of overpressuring in the Gulf of Cadiz. Fluid venting is triggered by the formation of overpressured compartments that develop beneath thrust structures, which provide migration conduits for hydrocarbon-enriched fluids and lateral compressional stress (Lowrie et al., 1999; Somoza et al., 2003). On the lower slope, the compressional stress at the toe of the AUGC, enhanced by the subsequent extensional collapse that took place after its emplacement, could be responsible for forming overpressured compartments that could provide avenues of hydrocarbon-enriched fluids.

\subsection{Triggering mechanisms for fluid expulsion}

\subsubsection{Mud volcano systems and diapirism}

Mud volcanoes are related to diapiric structures of various natures that facilitate the ascent of fluids and/or can work as fluid sources. On the Iberian margin most mud volcanoes on the middle slope are aligned with the main NE-SW trending diapiric ridges located between a NE-SW basement high (Guadalquivir Bank) and one of the main fronts of the Betic external zones (FSb in Fig. 1A). Diapirism and genesis of diapiric ridges were probably favoured by the plasticity of the marls and salts and by the overload and overpressure produced by the thrusting sheets of the external Betic zones, including the AUGC, as they advanced northwestwards over a narrow basin, where the Variscan basement (Guadalquivir Bank, Fig. 1) occupies an elevated position and constitutes a rigid block which stops the advance of the thrust sheets to the NW.

Mud volcanoes are found above diapirs with different burial depths (Figs. 5 and 8). In each case the subsurface mud volcano system appears to be different. Mud volcanoes related to shallow diapirs show a multi-feeder system with several seismic chimneys connected to the superficial structure (e.g. the Cornide and Ibérico mounds, Fig. 7). When diapirs are found at higher depths, as occurs in the Gades mud volcano system (Fig. 4), the conduit that links the diapir and the mud volcano appears very well defined, and in this case it corresponds to a deep fault. Deeper diapirs, like the one related to the Tasyo mud volcano, a small structure which pierces the sea-floor at $1300 \mathrm{~m}$, are associated with a more developed system represented by a stack of bicones (Fig. 8). These bicones are formed by the building of a external edifice followed by collapse and subsidence (Fig. 10).

To date, mud volcanoes have only been related to the marly diapirism associated with the AUGC. In this work, we propose that salt diapirism is also an important factor, especially on the lower slope,

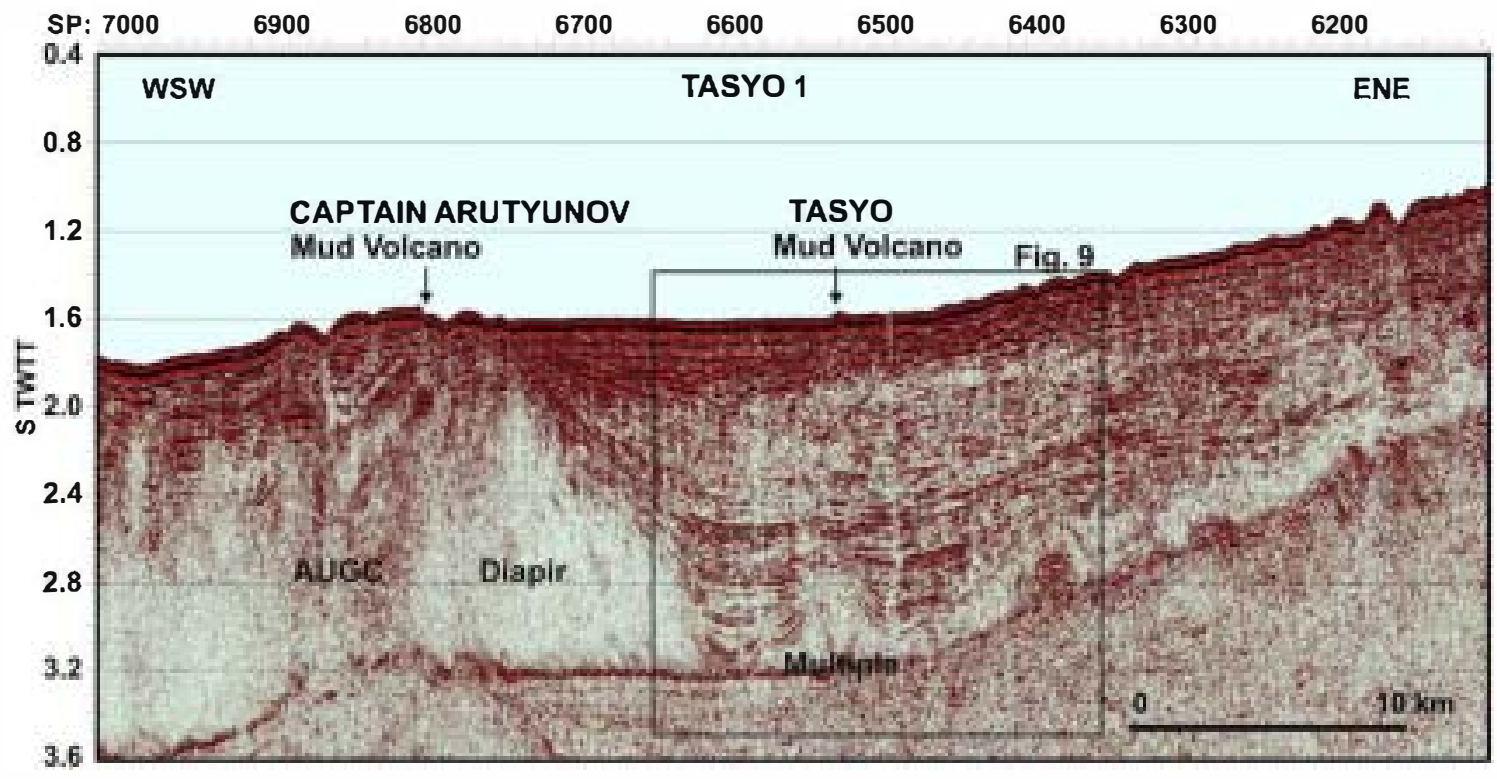

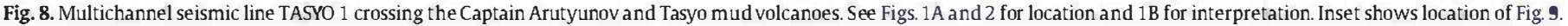



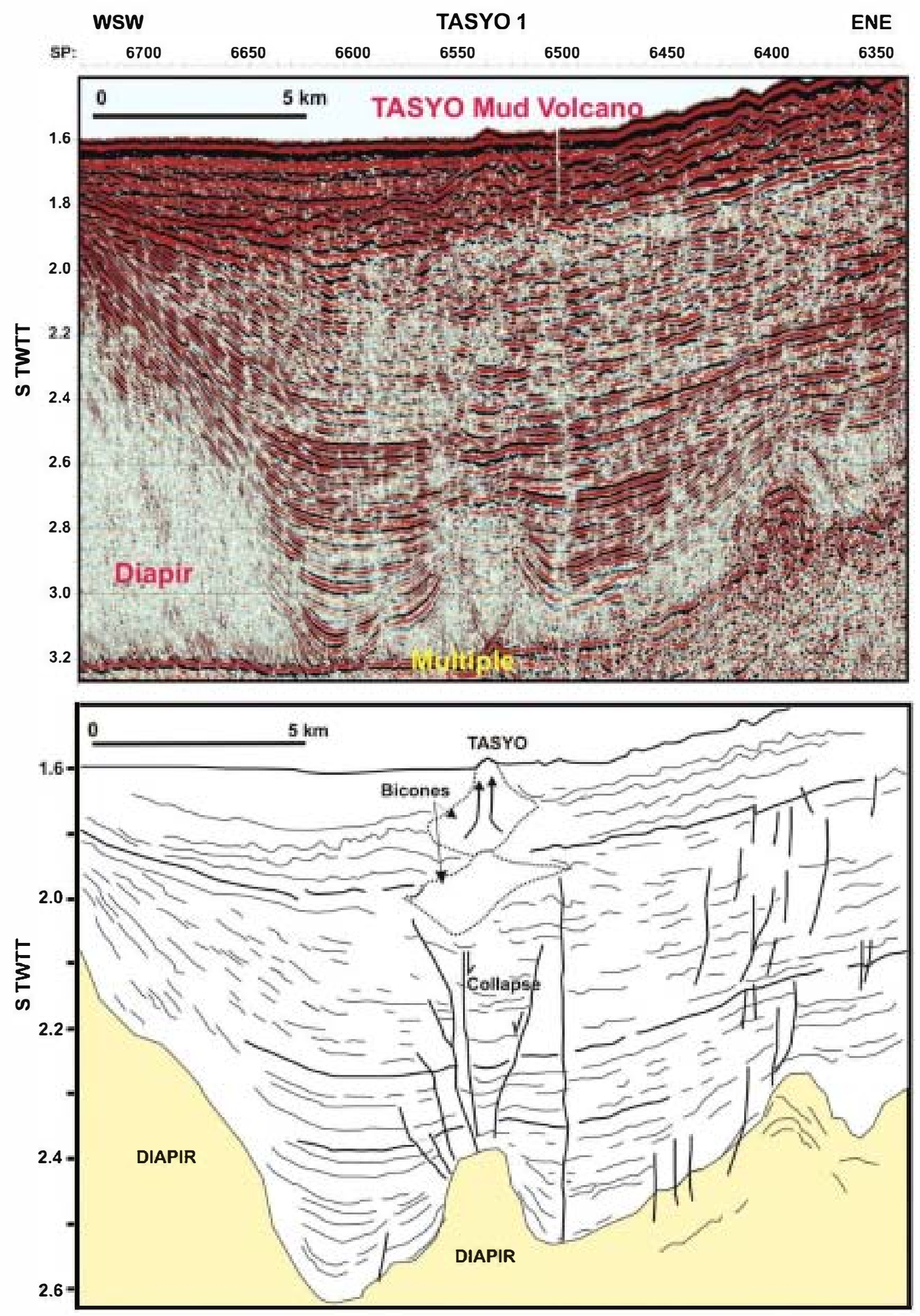

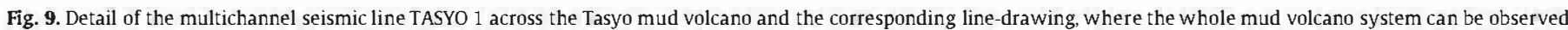
including the stack of two bicones. See Figs. 2 and 8 for location.

where the salt diapirs can drag the existing fluids in the units they cross in their upward movement, and therefore facilitate the fluid migration to the sea-floor. The low number of mud volcanoes on the lower slope in comparison with the Iberian-Moroccan upper-middle slope could be related to a lesser development of diapirs, though other factors can be considered. 

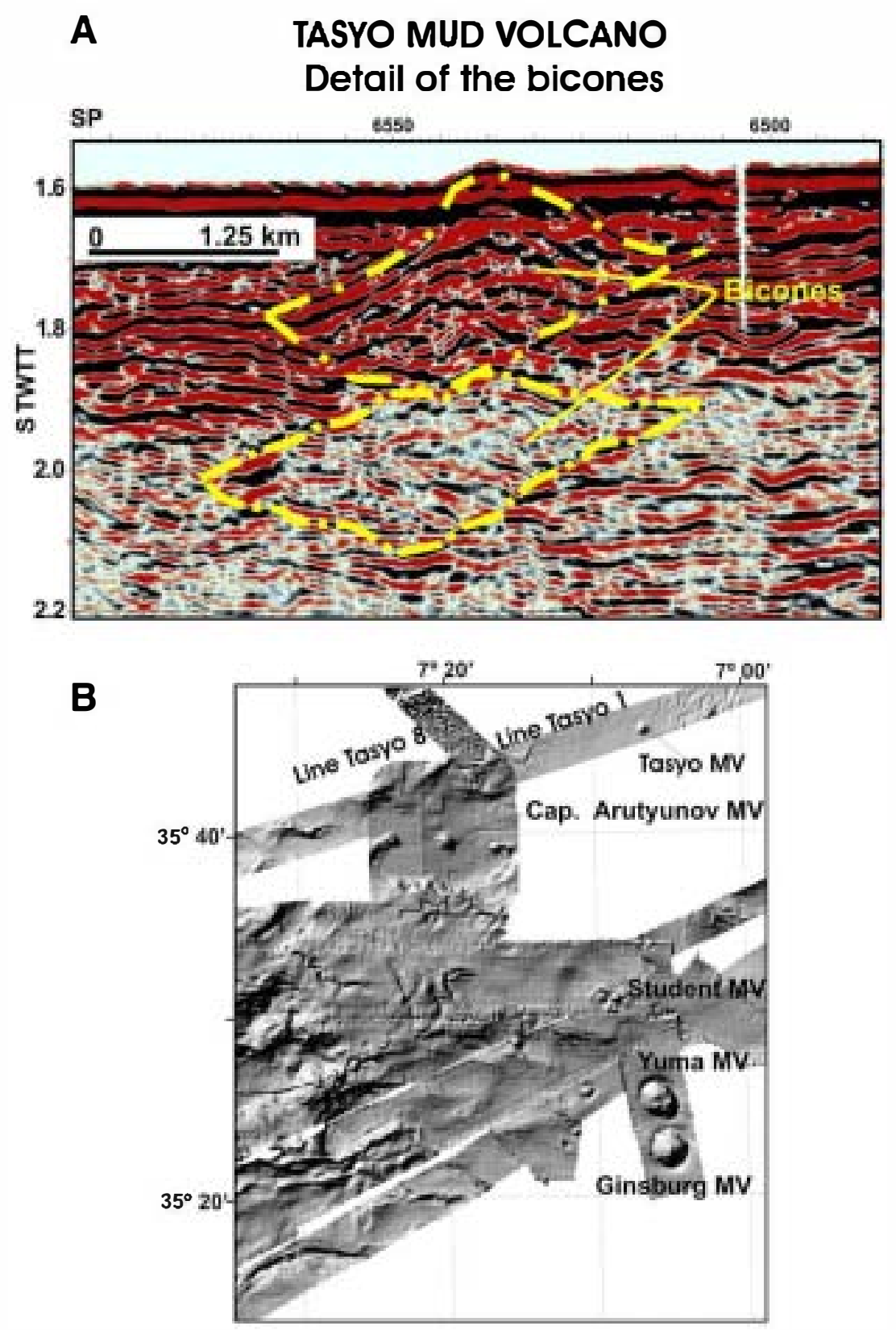

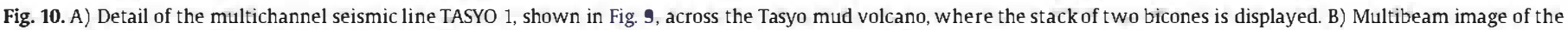
Tasyo mud volcano (constructed with data from TASYO and GAP cruises, Kopf et al., 2004).

\subsubsection{Mud volcanoes and faults}

Faults act as the feeder systems that connect the source and the superficial mud volcano edifices. Fluid migration through the sediments to the sea-floor appears to be controlled by faulting, since some of the mud volcanoes and mud-carbonated mounds are aligned following the NE-SW and NW-SE direction of major faults and the $\mathrm{NE}-\mathrm{SW}$ trending diapiric ridges related to AUGC thrusts in the NE sector of the Gulf of Cádiz.

It has been proposed that major mud volcanoes and gas-related features are determined by fault systems associated with diapiric activity. This assumption can be applied to the Iberian margin but not to the lower slope, where tectonic structures such as thrust faults, unrelated to diapirs affecting the AUGC, act as escape pathways for fluids. On the lower slope, the mud volcanoes identified so far seem to be linked to arcuate fronts that represent the thrust sheets of the AUGC or in other cases to strike-slip faults (Pinheiro et al., 2006).

\section{Conclusions}

- There is a close relationship between fluid escape structures and tectonic structures determined by the development of the BeticRifean orogen and the neotectonic activity that took place under the convergent regime between the African and Eurasian plates. In the Gulf of Cádiz tectonics related to the compressive regime represents the major control for fluid migration.

- It is inferred from seismic images that mud volcanoes are tectonically controlled by structures resulting from the NW compressional regime. Diapirism is a key factor in mud volcano development, as can be concluded from seismic images, in which mud volcanoes are always found above or associated with diapirs at different burial depths. It has been determined that not only marly diapirism related to the AUGC is important, but also salt diapirism. Diapirs and faults allow overpressured muds and fluids to be extruded to the surface. In the first step mud volcanoes and 


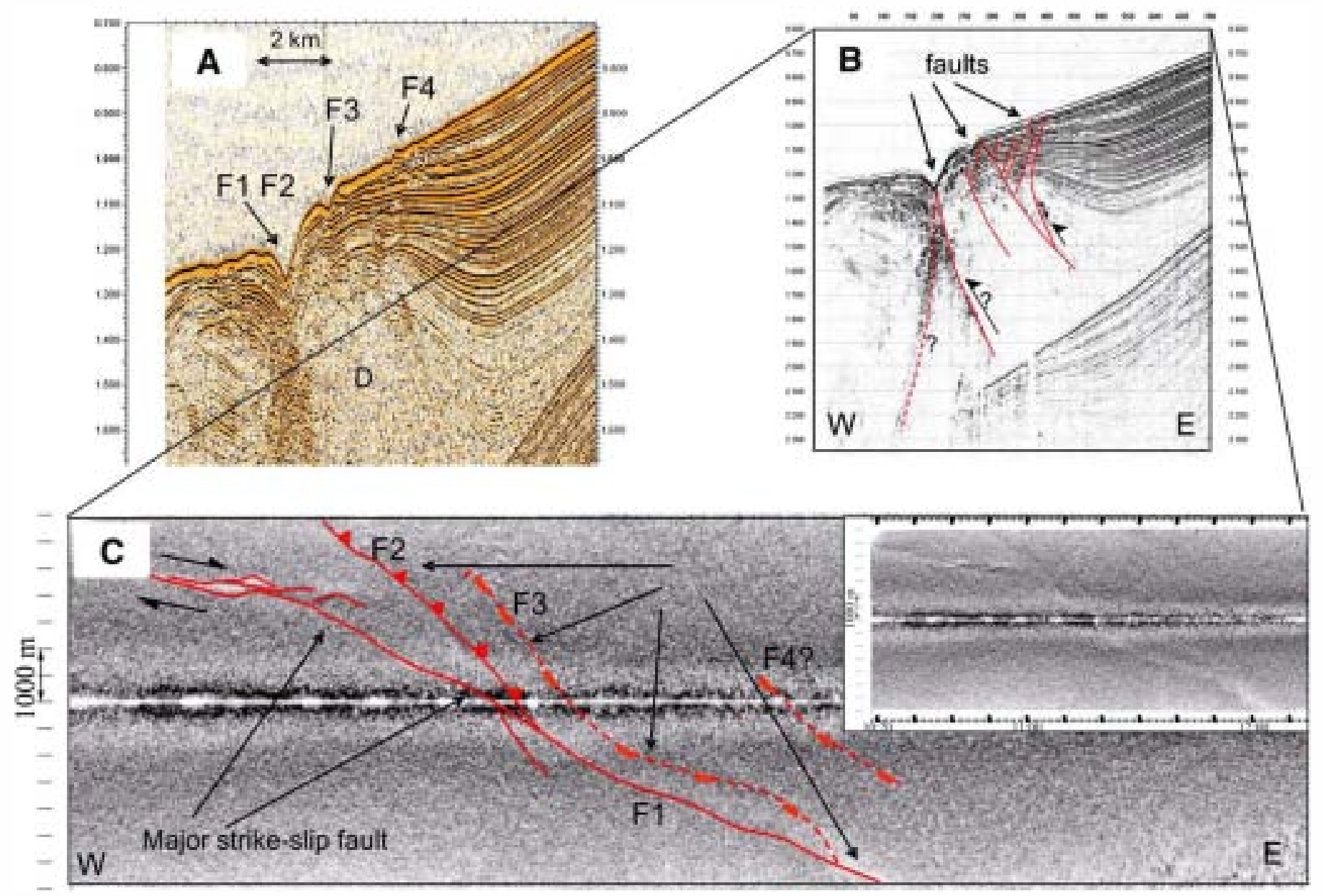

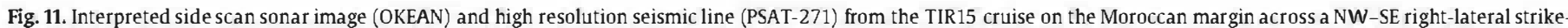

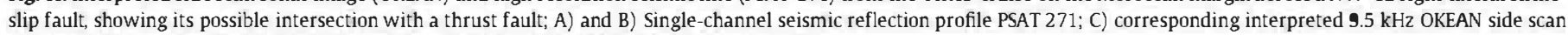
sonar profile. Inset in (C) shows uninterpreted data. D: mud(?) diapir. See Fig. 2 for location.

fluid venting are related to diapiric development. In each case the subsurface mud volcano system appears to be different. Overpressured sediments find their way up to the surface along fault planes. Mud volcanoes have been observed in connection with normal faults, strike-slip and thrust faults.

- We proposed a broad division of mud volcanoes into two groups according to their distribution, their relationship with tectonics and diapirism, the nature of diapirism, the tectonic setting, the characteristics and thickness of the AUGC and fault-control. The first group consists of the mud volcanoes and mud-carbonate mounds found on the Betic-Rifean margin at 350 and $2000 \mathrm{~m}$ depth, and the second group comprises all the mud volcanoes found on the lower continental slope at 2300-3900 m depth. Whereas on the lower slope mud volcanoes are isolated, without

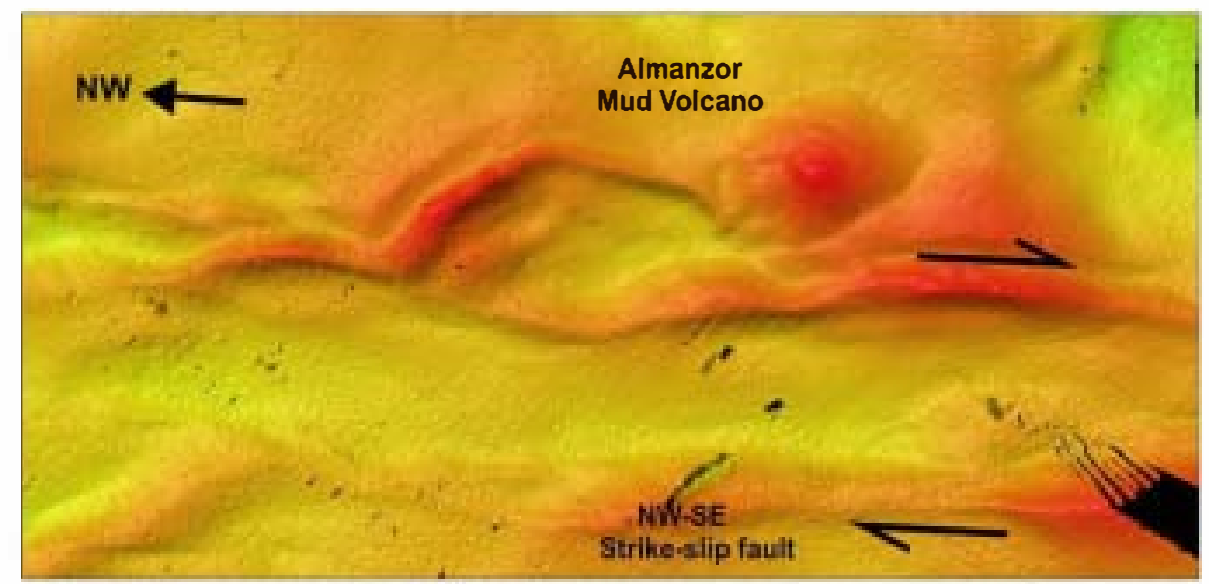

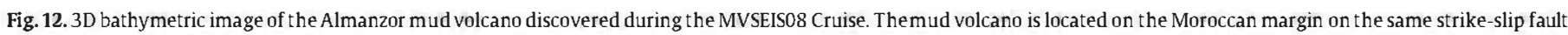
displayed in Fig. 11. See Fig. 2 for location. 


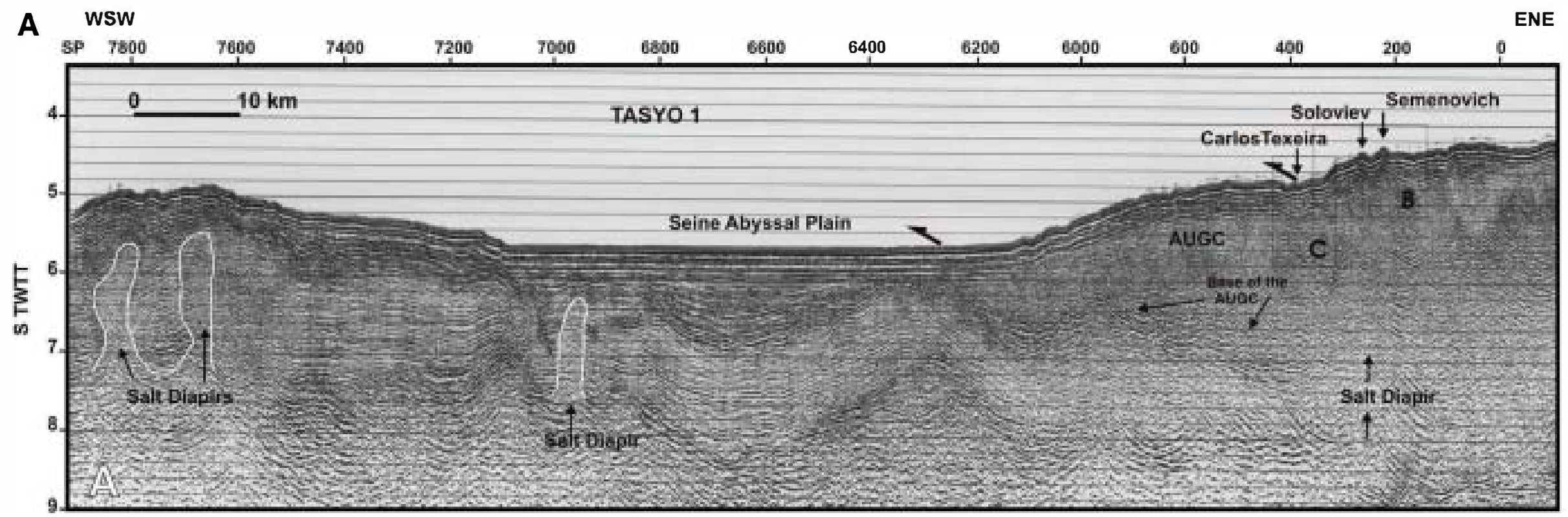

B
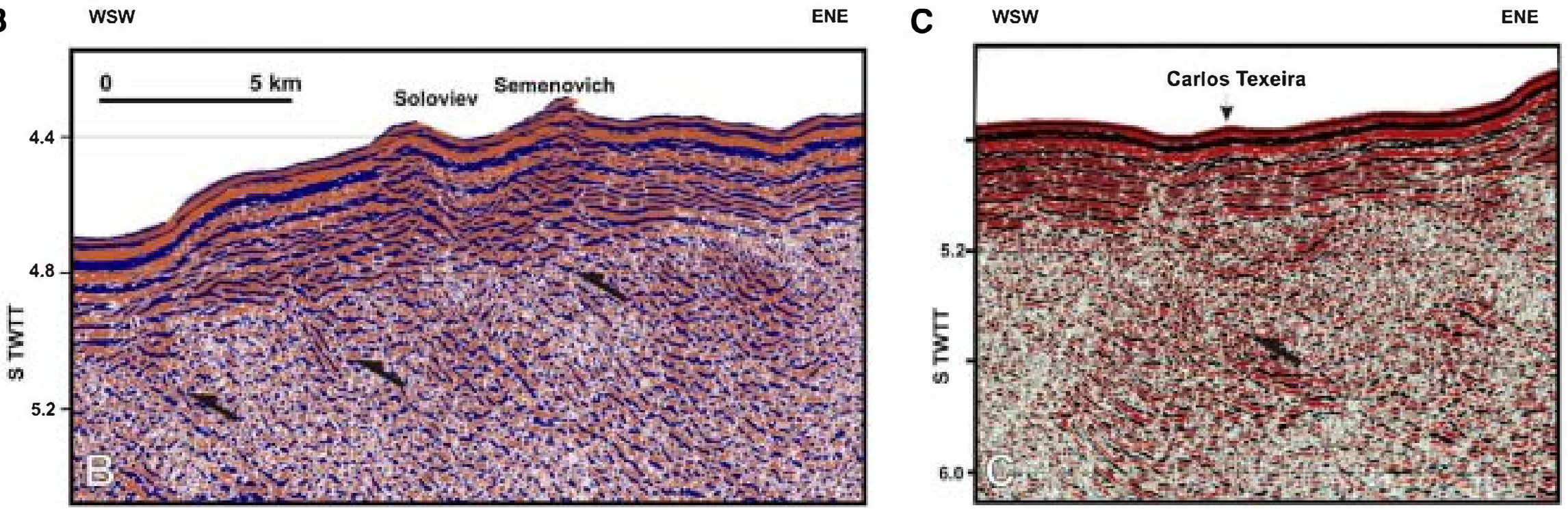

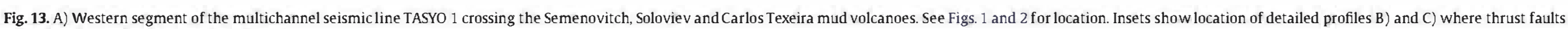
related to the mud volcanoes are indicated. 
any noticeable dominant trend, on the Betic Rifean margin mud volcanoes are clustered in several fields and in groups forming linear zones related to W-E to WNW-ESE dextral strike-slip faults or thrust faults and diapirs.

\section{Acknowledgements}

We thank all those who participated in the research cruises of the TASYO project and the TTR Cruises, especially the captains and crews of the research vessels $B / O$ Cornide de Saavedra, B/O Hespérides and Professor Logachev. We are also very grateful to Emilia Gulmezova for multichannel seismic data processing. This research was funded by the Spanish Marine Science and Technology Programme, under the TASYO Project (MAR 98-0209) and the GADES Project (REN2002-04117-C03/ MAR) within the framework of the Spanish-Portuguese agreement for scientific co-operation. The TIR-15 cruise was funded by the MVSEIS project, jointly with the UNESCO/IOCTTR Programme and Moscow State University. This work is a contribution to the ESF EuroCORE-EuroMARGINS projects MVSEIS (O1-LEC-EMA24F /PDCIM72003/DIV/ 40018, REN2002-11669-EMAR) and MOUNDFORCE (O1-LEC-EMA06F, REN2002-11668-E-MAR). It is also a contribution to the ConsoliderIngenio 2010 CSD2006-0041-“TOPOIBERIA".

\section{References}

Baraza, J., Ercilla, G., 1996. Gas-Charged sediments and large pockmark-like features on the Gulf of Cádiz slope (SW Spain). Mar. Pet. Geol. 13 (2), 253-261.

Bohrmann, G., Ivanov, M., Foucher, J.-P., Spiess, V., Bialas, J., Greinert, J., Weinrebe, W Abegg, F., Aloisi, G., Artemov, Y., Blinova, V., Drews, M., Heidersdorf, F., Krabbenhöft, A., Klaucke, I., Krastel, S., Leder, T., Polikarpov, I., Saburova, M., Schmale, O., Seifert, R., Volkonskaya, A., Zillmer, M., 2003. Mud volcanoes and gas hydrates in the Black Sea: new data from Dvurechenskii and Odessa mud volcanoes. Geo-Mar. Lett. 23. 239-249.

Camerlenghi, A, Cita, M.B., Della Vedova, B., Fusi, N., Mirabile, L, Pellis, G., 1995. Geophysical evidence of mud diapirism on the Mediterranean Ridge Accretionary Complex. Mar. Geophys. Res. 17, 115-141.

Casas, D., Ercilla, G., Baraza, J., 2003. Acoustic evidences of gas in the continental slope sediments of the Gulf of Cádiz (E Atlantic). Geo-Mar. Lett. 23, 300-310.

Dewey, J.F., Helman, M.L., Turco, E., Hutton, D.H.W., Knott, S.D., 1989. Kinematics of the Western Mediterranean. In: Coward, M.P., Dietrich, D., Park, R.G. (Eds.), Alpine Tectonics. Geol. Soc. London Spec. Publ., vol. 45, pp. 265-283.

Díaz-del-Río, V., Somoza, L., Martínez-Frías, J., Mata, M.P., Delgado, A., Hernández Molina, F.J., Lunar, R., Martín-Rubí, J.A., Maestro, A., Fernández-Puga, M.C., León, R. Llave, E., Medialdea, T., Vázquez, J.T., 2003. Vast fields of hydrocarbon-derived carbonate chimneys related to the accretionary wedge/olistostrome of the Gulf of Cádiz Mar. Geol. 195, 177-200.

Dimitrov, L.I., 2002. Mud volcanoes-the most important pathway for degassing deeply buried sediments. Earth Sci. Rev. 59, 49-76.

Fernández-Puga, M.C., Vázquez,J.T., Somoza, L., Díaz del Río, V., Medialdea, T., Mata, M.P. León, R., 2007. Gas-related morphologies and diapirism in the Gulf of Cádiz. GeoMar. Iett. 27 (2-4), 213-221.

Feyzullayev, A.A., Kadirov, F.A., Aliyev, C.S., 2005. Mud volcano model resulting from geophysical and geochemical research. In: Martinelli, G., Panahi, B. (Eds.), Mud Volcanoes, Geodynamics and Seismicity. NATO Science Series. Springer, The Netherlands, pp. 251-262.

García Mojonero, C., Martínez del Olmo, W., 2001. One sea level fall and four different gas plays: the Gulf of Cádiz Basin, SW Spain. In: Fillon, R.H., Rosen, N.C. (Eds.) Program and Abstracts, GCSSEMP Foundation 21st Annual Bob F. Perkins Research Conference, pp. 357-367.

Gardner, J.M., 2001. Mud volcanoes revealed and sampled on the Western Moroccan continental margin. Geophys. Res. Lett. 28 (2), 339-342.

González, F.J., Somoza, L., Lunar, R., Martínez-Frías, J., Martín Rubí, J.A., Torres, T., Ortiz, E J., Díaz del Río, V., Pinheiro, L.M., Magalhaes, V., 2009. Hydrocarbon-derived ferromanganese nodules in carbonate-mud mounds from the Gulf of Cádiz: mudbreccia sediments and clasts as nucleation sites. Mar. Geol. 261, 64-81 (this issue).

Guliyev, I.S., Feizullayev, A.A., 1997. All about mud volcanoes. NAFГA Press Publ. House, Baku. 120 pp.

Gutscher, M.A., Malod, J., Rehault, J.P., Contrucci, I., Klingelhoefer, F., Mendes-Victor, L., Spakman, W., 2002. Evidence for active subduction beneath Gibraltar. Geology 30 (12), 1071-1074

Hensen, C., Nuzzo, M., Hornibrook, E., Pinheiro, L.M., Bock, B., Magalhães, V., Bruckman, W., 2007. Sources of mud volcano fluids in the Gulf of Cádiz-indications for hydrothermal imprint. Geochim. Cosmochim. Acta 71, 1232-1248.

Hernández-Molina, J., Llave, E., Somoza, L., Fernández-Puga, M.C., Maestro, A., León, R. Medialdea, T., Barnolas, A., García, M., Díaz-del-Río, V., Fernández-Salas, L.M., Vázquez, J.T., Lobo, F., Alveirinho Dias, J., Rodero, J., Gardner, J., 2003. Looking for clues to paleoceanographic imprints: a diagnosis of the Gulf of Cádiz Contourite Depositional Systems. Geology 31, 19-22.
Huguen, C., Mascle, J., Chaumillon, E., Kopf, A., Woodside, J., Zitter, T., 2004. Structura setting and tectonic control of the mud volcanoes from the central Mediterranean Ridge (Eastern Mediterranean). Mar. Geol. 209, 245-263.

Iribarren, L., Vergés, J., Camurri, F., Fullea, J., Fernández, M., 2007. The structure of the Atlantic-Mediterranean transition zone from the Alboran Sea to the Horseshoe Abyssal Plain (Iberia-Africa plate boundary). Mar. Geol. 243, 97-119.

Ivanov, M.K., Kenyon, N., Nielsen, T., Wheeler, A, Monteiro, H., Gradner, J., Comas, M. Akhmanov, A., Akhmetzhanov, G., 2000. Goals and principal results of the TTR-S cruise. 10C/Unesco Workshop Report 168, pp. 3-4.

Kopf, A., 2002. Significance of mud volcanism. Rev. Geophys. 40 (2). doi:10.1029/ 2000RG000093.

Kopf, A., Cruise Participants, 2004. Report and preliminary results of SONNE Cruise SO175, Miami-Bremerhaven, 12.11-30.12.2003. Berichte, fachbereich Geowissenschaften, Universitãt Bremen. No 228, 218 pp.

León, R., Somoza, L., Ivanov, M.K., Díaz-del-Río, V., Iobato, A., Hernández-Molina, F.J. Fernández-Puga, M.C., Maestro, A., Medialdea, T., Alveirinho-Dias, J.M., Vázquez, T. 2001. Seabed morphology and gas venting in the Gulf of Cádiz mudvolcano area: imagery of multibeam data and ultra-high resolution data. In: Akhmanov, G Suzyumov, A. (Eds.), Geological Processes on Deep-water European Margins. IOC Workshop Report, vol. 175, pp. 43-45.

León, R., Somoza, L., Medialdea, T., Maestro, A., Díaz-Del-Río, V., Fernandez-Puga, M.C. 2006. Classification of sea-floor features associated with methane seeps along the Gulf of Cádiz continental margin. Deep-Sea Res. 53, 1464-1481.

León, R., Somoza, L, Medialdea, T., González, F.J., Díaz del Río, V., Fernández-Puga, M.C. Maestro, A., Mata, M.P., 2007. Sea-floor features related to hydrocarbon seeps in deepwater carbonate-mud mounds of the Gulf of Cádiz: from mud flows to carbonate precipitates. Geo-Mar. Iett. 27 (2-4), 237-247.

Lonergan, L., White, N., 1997. Origin of the Betic-Rif mountain belt. Tectonics 16 (3) 504-522.

Lowrie, A., Hamite, R., Moffett, S., Somoza, L., Maestro, A, Lerche, I., 1999. Potential pressure compartments sub-salt in the Gulf of Mexico and beneath massive debris flows in the Gulf of Cádiz. 19th Annual Bob. F. Perlins Conference Abstracts, Advanced Reservoir Characterization for the 21st Century. GCSSEPM Foundation, Houston, Texas, USA, pp. 271-280.

Maestro, A., Somoza, L., Medialdea, T., Talbot, C.J., Lowrie, A., Vázquez, J.T., Díaz-del-Río V., 2003. Large-scale slope failure involving Triassic and Middle Miocene salt and shale in the Gulf of Cádiz (Atlantic Iberian Margin). Terra Nova 15, 380-391.

Magalhães, V., Vasconcelos, C., Pinheiro, L., Gaspar, L., Ivanov, M., Díaz-del-Río, V., Somoza L, Gadner, J., 2004. Methane related autigenic carbonates, chimneys and crust, from the Gulf of Cádiz. 32nd Intemational geological congress. Florence (Italy), 2004 International Union of Geological Science (IUGS). In: T18.01-Deep biosphere. CDROM

Maldonado, A., Somoza, L., Pallarés, L, 1999. The Betic orogen and the Iberian-African boundary in the Gulf of Cádiz: geological evolution (central North Atlantic). Mar. Geol. 155, 9-43.

Mazurenko, L.L., Soloviev, V.A., Gardner, J.M., Ivanov, M.K., 2003. Gas hydrates in the Ginsburg and Yuma mud volcano sediments (Moroccan margin): results of chemical and isotopic studies of pore water. Mar. Geol. 195, 201-210.

Medialdea, T., 2007. Estructura y evolución tectónica del Golfo de Cádiz. Pub. Instituto Geológico y Minero de España, Serie Tesis Doctorales, $n^{\bullet}$ 8, Madrid. 328 pp.

Medialdea, T., Vegas, R., Somoza, L., Vázquez, J.T., Maldonado, A., Díaz-del-Río, V., Maestro, A., Córdoba, D., Fernández-Puga, M.C., 2004. Structure and evolution of the "Olistostrome" complex of the Gibraltar Arc in the Gulf of Cádiz (eastern Central Atlantic): evidence from two long seismic cross-sections. Mar. Geol. 209, 173-198.

Milkov, A.V., 2000. Worlwide distribution of submarine mud volcanoes and associated gas hydrates. Mar. Geol. 167, 29-42.

Orange, D.L., Greene, H.G., Reed, D., Martin, J.B., McHugh, C.M., Ryan, W.B.F., Maher, N., Stakes, D., Barry, J., 1999. Widespread fluid expulsion on a translational continental margin: mud volcanoes, fault zones, headless canyons, and organic-rich substrate in Monterey Bay, California. GSA Bull. 111, 992-1009.

Ovsyannikov, D.O., Sadekov, A.Y., Kozlova, E.V., 2003. Rock fragments from mud volcanic deposits of the Gulf of Cádiz: an insight into the Eocene-Pliocene sedimentary succession of the basin. Mar. Geol. 195, 211-221.

Panahi, B.M., 2005. Mud volcanism, geodynamics and seismicity of Azerbaijan and the Caspian Sea region. In: Martinelli, G., Panahi, B. (Eds.), Mud Volcanoes, Geodynamics and Seismicity. NATO Science Series. Springer, The Netherlands, pp. 89-104

Pautot, G., Auzende, J.M., Le Pichon, X., 1970. Continuous deep sea salt layer along north Atlantic margins related to early phase of rifting. Nature 227, 351-354.

Pinheiro, L., Ivanov, M.K., Sautkin, A., Akhmanov, G., Magalhães, V., Volkonskaya, A., Monteiro, J.H., Somoza, L., Gardner, J., Hamouni, N., Cunha, M.R., 2003. Mud volcanism in the Gulf of Cádiz: results from the TTR-10 cruise. Mar. Geol. 195, 131-151.

Pinheiro, L.M., Magalhães, V., Somoza, L., Gardner, J., Ivanov, M., Kopf, A., Rensbergen, P.V., Monteiro, J.H., Euromargins-MVSEIS Team, 2006. Structural control of mud volcanism and hydrocarbon-rich fluid seepage in the Gulf of Cádiz: recent results from the TTR-15 cruise. In: Mascle, J., Sakellariou, D., Briand, F. (Eds.), Fluid Seepages/Mud Volcanoes in the Mediterranean and Adjacent Domains. CIESM Workshop Monographs, vol. 29, pp. 53-58. Monaco.

Pinheiro, L.M., Roque, C., Schwenk, F., Ding, J., Crespo, J., González, F.J., Belova, A., Lemos, C., Duarte, J., El Fellah, B., 2007. Seismic data. Preliminary results of investigations during the TIR-15 of R.V. "Prof. Logachev". Cruise Report. Deep-water cold seeps, sedimentary environments and ecosystems of the Black and Thyrrenian Seas and the Gulf of Cadiz Intergovernmental Oceanographic Commission Technical Series, UNESCO Paris 72, 59-66.

Rosenbaum, G., Lister, G.S., Duboz, C., 2002. Relative motions of Africa, Iberia and Europe during Alpine orogeny. Tectonophysics 359, 117-129.

Royden, L.H., 1993. Evolution of retreating subduction boundaries forms during continental collision. Tectonics 12 (3), 629-638. 
Schwenk, T., Pinheiro, L., Roque, C., Fokin, I., Pinto, C., TIR15/4 scientific crew, 2006 Imaging mud volcanoes and tectonic structures in the Gulf of Cádiz-first seismic results of TIR15/4. Workshop Report. Intergovernmental Oceanographic Commission, Moscow, p. 89

Somoza, L, Maestro, A., Lowrie, A., 1999. Allochthonous blocks as hydrocarbon traps in the Gulf of Cádiz. Offshore Technol Conf. 10889, 571-577.

Somoza, L., Ivanov, M.K., Pinheiro, L, Maestro, A., Iowrie, A., Vázquez, J.T., Gardner, J. Medialdea, T, Fernández-Puga, MC 2001. Structural and tectonic control of fluid seeps and mud volcanoes in the Gulf of Cádiz. In: Akhmanov, G., Suzyumov, A (Eds.), Geological processes on deep-water European margins. IOC Workshop Report, vol 175, pp. 41-42.

Somoza, L, Gardner, J., Díaz-del-Río, V., Vázquez,J.T., Pinheiro, L.M., Hernández-Molina, F.J., TASYO/ANASTASYA shipboard scientific parties, 2002. Numerous methane gas related sea floor structures identified in the Gulf of Cádiz. Eos Trans. AGU 83 (47) 541-549.

Somoza, L, Díaz-del-Río, V., León, R., Ivanov, M., Fernández-Puga, M.C., Gardner, J.M., Hernández-Molina, F.J., Pinheiro, L.M., Rodero, J., Lobato, A., Maestro, A., Vázquez,J.T., Medialdea, T., Fernández-Salas, L.M., 2003. Seabed morphology and hydrocarbon seepage in the Gulf of Cádiz mud volcano area: acoustic imagery, multibeam and ultrahigh resolution seismic data Mar. Geol 195, 153-176.

Somoza, L, MVSEIS_08 Team, 2008. New discovery of mud volcanoes related to active strike-slip faults and thrusting ridges in the Moroccan margin (Gulf of Cadiz,
Eastern CentraIAtlantic). 9th International Conference on Gas in Marine Sediments, Bremen. 2 pp.

Stadniskaia, A., Ivanov, M.K., Blinova, V., Kreulen, R., van Weering, T.C.E., 2006. Molecular and carbon isotopic variability of hydrocarbon gases from mud volcanoes in the Gulf of Cádiz, NE Atlantic. Mar. Pet. Geol 23, 281-296.

Stewart, S.A., Davis, R.J, 2006. Structure and emplacement of mud volcano systems in the South Caspian Basin. AAPG Bull. 90 (5), 771-786.

Terrinha, P A Ribeiro, C Kullberg J.C., Iopes, C. Rocha, R. Ribeiro, A 2002 Compressive episodes and faunal isolation during rifting, Southwest Iberia. J. Geol 110, 101-113.

Torelli, L., Sartori, R., Zitellini, N., 1997. The giant chaotic body in the Atlantic Ocean off Gibraltar: new results from a deep seismic reflection survey. Mar. Pet. Geol 14, 125-138.

Van Rensbergen, P., Depreiter, D., Pannemans, B., Moerkerke, G., van Rooij, D., Marsset, B., Akhmanov, G., Blinova, V., Ivanov, M., Rachidi, M., Magalhaes, V., Pinheiro, L, Cunha, M., Henriet, J.P., 2005. The Arraiche mud volcano field at the Moroccan Atlantic slope, Gulf of Cádiz. Mar. Geol 219, 1-17.

Vázquez, J.T., Vegas, R., 2000. Estilos diferentes de deformación en el limite de placas entre Africa y Eurasia, desde el Arco de la Herradura al Mar de Alborán. $2^{*}$ Asamblea Hispano Portuguesa de Geodesia y Geofísica 19, 147-148.

Yusifov, M., Rabinowitz, P.D., 2004. Classification of mud volcanoes in the South Caspian Basin, off shore Azerbaijan. Mar. Pet. Geol 21, 965-975. 